DOI: https://doi.org//10.32839/2304-5809/2020-83.1-4

UDC 811.111'42

Balatska Olena

National University "Yuri Kondratyuk Poltava Polytechnic"

Ayanda Noma

South Africa Daily, South Africa, Pretoria

\title{
HEDGING IN CRITICAL REMARKS IN THE ENGLISH-LANGUAGE RESEARCH ARTICLES IN PSYCHOLOGY
}

Summary. The article studies peculiarities of using hedging in the English-language research articles in Psychology, whereas the research article is considered to be the most important genre of the modern English-language scientific discourse. The article presents types of hedges used in critical remarks in research articles in Psychology. Quantitative analysis of using hedges in these research articles has been carried out whose results have demonstrated that most critical remarks in the English-language research articles in Psychology are hedged. It has been shown that the most numerous hedges in the English-language research articles in Psychology are modal verbs expressing possibility, passive voice, and approximators, whereas possibility / probability adverbs and adjectives, expressions showing the authors' personal doubt and direct involvement, semi-auxiliaries, impersonal constructions, and time deictics are used in a significantly smaller number of critical remarks. Keywords: English-language scientific discourse, genre, research article in Psychology, critical remark, hedging, hedges.

Балацька О.Л.

Національний університет «Полтавська політехніка імені Юрія Кондратюка»

Аянда Нома

Дослідницький відділ Дейлі, Південна Африка

\section{ЗАСОБИ ХЕДЖИНГУ У КРИТИЧНИХ ЗАУВАЖЕННЯХ

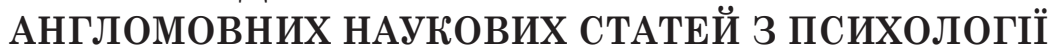

Анотація. У статті розглядаються особливості використання засобів хеджингу в англомовних наукових статтях з психології, одному з видів провідного жанру сучасного англомовного наукового дискурсу - статті. Описано низку досліджень, що стали теоретичним підгрунтям для заснування та розвитку концепції хеджування в сучасній науковій парадигмі. У результаті аналізу фрактичного матеріалу було виокремлено типи хеджів, які зазвичай застосовуються у критичних зауваженнях авторами сучасних англомовних наукових статей з психології. У роботі представлено кількісний аналіз використання засобів хеджингу, які відносяться до кожного виокремленого типу. Здійснений аналіз продемонстрував і довів, що більшість критичних зауважень в англомовних наукових статтях з психології містять різноманітні засоби хеджингу, що спричинено особливостями сучасного англомовного наукового дискурсу. Крім того, було виявлено, що найбільшу питому вагу серед засобів хеджингу, котрі використовуються авторами у критичних зауваженнях у статтях зазначеного типу, найбільшу питому вагу мають модальні дієслова, які виражають можливість / вірогідність, пасивний стан дієслова, а також апроксиматори (кількісні прислівники, прислівники ступеню, частотності та часу й епістемічні дієслова, які зазвичай уживаються у критичних зауваженнях у поєднанні з іншими засобами хеджингу). Натомість такі засоби хеджингу, як прислівники та прикметники, котрі виражають можливість / вірогідність, вирази, які вербалізують особисті сумніви адресанта щодо повноти його знань або актуалізують наявність у нього точки зору, відмінної від висловленої / висловлених раніше іншим / іншими науковцем / науковцями, дієслова-зв'язки, безособові конструкції, а також засоби темпорального дейксису у критичних зауваженнях актуалізованих в англомовних наукових статтях 3 психології застосовуються в порівняно меншій кількості випадків. До того ж, проведене нами дослідження показало, що у чималій частині критичних зауважень вербалізованих авторами у проаналізованих нами англомовних наукових статтях з психології використано декілька типів засобів хеджингу одночасно.

Ключові слова: англомовний науковий дискурс, жанр, наукова стаття з психології, критичне зауваження, засоби хеджингу, хеджи.

Tntroducing the problem. In today's worldwide transition from industrial/ postindustrial society to informational society, science plays an important role, so much attention is paid to the study of scientific discourse that helps scholars to disseminate their scientific achievements among their colleagues.

As the English language has become the language of international communication (lingua franca), the study of norms and peculiarities of English-language scientific communication is of particular importance for the present-day scientific community. Genres of scientific discourse often have such an important component as criticism that can be described as the driving force behind the development of scientific thought.

Therefore, the knowledge about scientific criticism in the English-language research article we believe to be useful both for the development of linguistic theory, and for practical use by Ukrainian scientists who are increasingly seeking integration into the world scientific community.

Analysis of previous literature. Scientists have been studying various aspects of English-language scientific discourse, in particular, its genres [8], among which the research article is considered 
to be the leading genre [13]. Criticism, as an obligatory component of the modern English-language research article, has already been the subject of research $[4 ; 6 ; 11 ; 12]$.

Identifying a knowledge gap in the filed of study. In the scientific literature, one can see papers which fragmentally analyze the use of hedges in critical remarks of the English-language research article [5; 12]. However, hedging in research articles in different academic disciplines, in particular in Psychology, hasn't been studied enough.

The purpose of the research article. The purpose of the article is to analyze hedging in the English-language research articles in Psychology.

The main body. Criticism, viewed as a negative evaluation judgement, is a discursive phenomenon - a scholar's mental activity and its verbal realization based on the corresponding fragment of knowledge and meant to reach the strategic aim, which is to expose and to eliminate the shortcomings of research activities [1, p. 1].

One of the peculiarities of the modern English-language scientific discourse is that English-speaking scientists are not inclined to use harsh or direct criticism in their papers [3; 10]. Using the latter may make those authors of the English-language research articles (RAs) the objects of similar criticism in the future. This may adversely affect their scientific reputation or the image of the scientific institutions for which they work [11, p. 76-77].

Because of this, English-speaking scientists are not interested in using strong and harsh criticism, but prefer using more subtle and disguised critical remarks [11, p. 78]. One of the means of achieving that is to use hedges that help the author of the RA to reduce their responsibility for the criticism, to express "socially expected doubt, hesitation, indirectness and politeness" [7, p. 148].

As a result of the analysis of the factual material, it was found that only $19.75 \%$ of all the critical remarks (CRs) are not hedged in RAs in Psychology, e.g.:

(1) There is paucity of information on the epidemiology of this disorder in the developing world, especially among university students. <...> In India, there has been only one study on social phobia (among high school adolescents) which mentions a prevalence of $12.8 \%$ and also an association with impairment in academic functioning.

(2) Psychometric testing in older adults, particular those over the age of 60 is limited across all instruments.

On the contrary, hedges are used in the vast majority of CRs in RAs in Psychology (80.15\% of all RAs in Psychology).

For the present study we have used the classification of hedges developed by Salager-Meyer [12, p. 7], which we supplemented with the types of hedges identified by Hyland [9] and Yarkho [2, p. 91], and have found out that the most numerous hedges in CRs in RAs in Psychology are:

- modal verbs expressing possibility $(26,83 \%$ of all hedges), e.g.:

(3) While the sample characteristics reflect the characteristics of the school populations, these findings may not generalize to other university populations.
(4) Furthermore, studies using questionnaires could have some inherent limitations too. The questionnaires cannot measure the psychological variables directly, and respondents may answer the questions superficially or they may intend to satisfy social desirability.

- passive voice (21,47 \% of all hedges), e.g.:

(5) Findings from this study indicate the need for further research among this population in two primary areas. First, additional focus groups should be held to explore the experiences of culturally and racially diverse family members of veterans, minor siblings of veterans, and family members who have joined formal organizations, such as Blue Star Mothers and Military Families Speak Out. Second, in addition to gathering qualitative data, surveys and scales to assess physical ailments, mental disorders (i.e., anxiety and depression), and help seeking behaviors should be implemented.

- approximators (adverbs of quantity; adverbs of degree; adverbs of frequency; adverbs of time; verbs expressing vagueness, imprecision, and variability) (19,85\% of all hedges), e.g.:

(6) On the other hand, studies on mental health in general and anxiety disorders in particular, often neglect a person's perception of his or her quality of life. Judging the impact of a mental disorder based on symptomatic distress, while ignoring one's overall quality of life, is incomplete.

(7) This finding suggests that the State Trait Anger Scale reflects the content domain of anger terms and phrases used by this sample of elderly individuals.

- possibility / probability adverbs and adjectives $(6,71 \%)$ :

(8) Our stimuli have only a dark limbal ring or no limbal ring; perhaps adding more subtle variations to the limbal rings would lead to more nuanced results.

(9) $<\ldots>>$ scholars who investigate the gendered divorce experience for men and women focus primarily on economic inequality, with men's socioeconomic status likely to be higher than women's.

- expressions showing the authors' personal doubt and direct involvement $(4,27 \%$ of all hedges), e.g.:

(10) To our knowledge, only two previous studies have examined the relationship between credit card debt and health-related characteristics among college students. ${ }^{(34,35)}$.

(11) As far as we know, Zuckerman's Alternative Five Personality traits, such as Sociability, have not been examined yet in relation to structural brain measures.

- semi-auxiliaries (4,01 \% of all hedges), e.g.:

(12) Regarding Extraversion, results seem to be inconsistent as we mentioned it before.

- impersonal constructions $(3,92 \%$ of all hedges), e.g.:

(13) However, it is not clear which factor of social life or social complexity causes this relationship.

- time deictics (3,02 \% of all hedges), e.g.:

(14) To date, no research has identified treatment options available for those with mental health problems in the primary care setting.

In addition, it was found that the authors of the RAs can use several types of hedges at the same timei.e. they use compound hedges (37,64 \% of all CRs): 
(15) Limitations

This study has some limitations. First, this study was conducted in a sample of students at 14 colleges and universities in the Midwest, a majority of which were female and Caucasian. While the sample characteristics reflect the characteristics of the school populations, these findings may not generalize to other university populations. Second, the low response rate to the Internet screening survey was also an issue and might suggest responder bias. <...> Third, these analyses were based on self-report data and, thus, some students may have been influenced to give socially desirable answers (i.e., minimize credit card debt, smoking, and other risky health behaviors). In addition, because this is a cross-sectional sample, it is difficult to ascertain the nature and development of the relationship between risky health behavior and credit card debt.

The CR above is hedged with using passive voice (was conducted, were based, have been influenced), approximator (some), modal verbs expressing possibility (may, might), epistemic verb (suggest), and impersonal construction (it is difficult).

(16) It may be that female participants in the present study were aware of their decreased willingness to help kin and friends in violent situations and therefore compensated by circling greater altruism ratings for the non-violent situations. This seems unlikely, but it could be possible since all participants were presented with all altruism ex- amples. Therefore this may represent a limitation of this study and perhaps future research could use altruism type as a between-subject variable to examine if this is the reason for the significant effect.

The hedges in CR 16 include modal verbs expressing possibility (may, could), semi-auxiliary (seems), impersonal construction (it could be possible), that has a possibility / probability adjective (possible), passive voice (were presented), and possibility / probability adverb (perhaps).

Conclusions and suggestions for further study. Thus, it is possible to conclude that most of the critical remarks in the English-language research articles in Psychology are hedged, which can be explained by the peculiarities of the modern Englishlanguage scientific discourse. There are several types of hedges in critical remarks in the English-language research articles in Psychology, among which the most widely used ones are modal verbs expressing possibility, passive voice, and approximators. Possibility / probability adverbs and adjectives, expressions showing the authors' personal doubt and direct involvement, semi-auxiliaries, impersonal constructions, and time deictics are rarely used. Besides, it has been shown that there is a tendency for authors of the English-language research articles to use one or more hedges in their critical remarks.

Future studies should focus on the use of hedges in the English-language research articles in other academic disciplines.

\section{References:}

1. Balatska O. L. (2013). Dyskursyvni vlastyvosti krytyky v anhlomovnii naukovii statti [Discursive Properties of Criticism in Research Articles in English]: avtoref. dys. ... kand. filol. nauk: spets. 10.02 .04 - hermanski movy. Kharkivskyi natsionalnyi universytet imeni V. N. Karazina. Kharkiv, 20 p.

2. Yarkho A. V. (2004). Kommunikativnaya stratehiya neuverenosti v sovremennom angloyazychnom dialogicheskom diskurse [Communicative strategy of uncertainty in contemporary. English dialogical discourse]: dis. ... kand. filol. nauk: spets. 10.02.04. Kh., 249 p.

3. Belcher D. (1995). Writing critically across the curriculum. Academic writing in a second language. Essays on research and pedagogy (ed. by D. Belcher and G. Braine). Norwood. New Jersey: Ablex Publishing Corporation, p. $135-155$.

4. Crossed Words: Criticism in Scholarly Writing (2011). (ed. Françoise Salager-Meyer, Beverly A Lewin). Peter Lang Publishing, Incorporated. $371 \mathrm{p}$.

5. Fagan A., Martin Martin P. (2004). The use of critical speech acts in psychology and chemistry research papers. Iberica. No. 8. P. 125-137.

6. Giannoni S. (2005). Negative Evaluation in Academic Discourse. A Comparison of English and Italian Research Articles. Linguistica e Filologia. No. 20. P. 71-99.

7. Hinkel E. (2002). Second Language Writers'Text: Linguistic and Rhetorical Features. London: Lawrence Erlbaum Associates Publishers. 370 p.

8. Hyland K. (2009). Academic Discourse: English In A Global Context. Bloomsbury. 256 p.

9. Hyland K. (1998). Hedging in Scientific Research Articles. Amsterdam: John Benjamins Publishing Company. 318 p.

10. Myers G. (1989). The pragmatic of politeness in scientific articles. Applied Linguistics. No. 10/1. P. 1-35.

11. Salager-Meyer F. (2001). From Self-Highlightedness to Self-Effacement : A Genre-Based Study of the SocioPragmatic Function of Criticism in Medical Discourse. LSP \& Professional Communication. Volume 1, Number 2. P. 63-84.

12. Salager-Meyer F. (1994). Hedges and textual communicative function in medical English written discourse. English for Specific Purposes. No. 13(2). P. 149-170.

13. Swales J. M. (1990). Genre Analysis: English in Academic and Research Settings. Cambridge: Cambridge Univ. Press, $260 \mathrm{p}$.

\section{Список літератури:}

1. Балацька О. Л. Дискурсивні властивості критики в англомовній науковій статті: авторедр. дис. ... канд. фрілол. наук: спец. 10.02.04 - германські мови. Харківський національний університет імені В.Н. Каразіна. Харків, 2013. 20 с.

2. Ярхо А. В. Коммуникативная стратегия неуверенности в современном англоязычном диалогическом дискурсе: дис. ... канд. фрилол. наук: 10.02.04. Х., 2004. 249 с.

3. Belcher D. Writing critically across the curriculum. Academic writing in a second language. Essays on research and pedagogy / Ed. by D. Belcher and G. Braine. Norwood. New Jersey : Ablex Publishing Corporation, 1995. P. $135-155$.

4. Crossed Words: Criticism in Scholarly Writing / Ed. Françoise Salager-Meyer, Beverly A Lewin. Peter Lang Publishing, Incorporated, 2011. 371 p. 
5. Fagan A., Martin Martin P. The use of critical speech acts in psychology and chemistry research papers. Iberica. 2004. No. 8. P. 125-137.

6. Giannoni S. Negative Evaluation in Academic Discourse. A Comparison of English and Italian Research Articles. Linguistica e Filologia. 2005. No. 20. P. 71-99.

7. Hinkel E. Second Language Writers' Text: Linguistic and Rhetorical Features. London : Lawrence Erlbaum Associates Publishers, 2002. 370 p.

8. Hyland K. Academic Discourse: English In A Global Context. Bloomsbury, 2009. 256 p.

9. Hyland K. Hedging in Scientific Research Articles. Amsterdam : John Benjamins Publishing Company, 1998. 318 p.

10. Myers G. The pragmatic of politeness in scientific articles. Applied Linguistics. 1989. No. 10/1. P. 1-35.

11. Salager-Meyer F. From Self-Highlightedness to Self-Effacement: A Genre-Based Study of the Socio-Pragmatic Function of Criticism in Medical Discourse. LSP \& Professional Communication. 2001. Volume 1, Number 2. P. 63-84.

12. Salager-Meyer F. Hedges and textual communicative function in medical English written discourse. English for Specific Purposes. 1994. No. 13(2). P.149-170.

13. Swales J. M. Genre Analysis: English in Academic and Research Settings. Cambridge: Cambridge Univ. Press, 1990. $260 \mathrm{p}$. 